\title{
Metodologi Eco Desain Yang Digunakan Untuk Pengembangan Produk Furniture Berbasis Logam Secara Berkelanjutan
}

\author{
Rusdiyantoro ${ }^{1} \&$ Yunia Dwie Nurcahyanie ${ }^{2}$ \\ 1,2) Teknik Indusri, Fakultas Teknologi Industri, Universitas PGRI Adi Buana Surabaya \\ JI. Dukuh Menanggal XII.4, Surabaya 60234 \\ Email : rusdi2008@yahoo.com
}

\begin{abstract}
Abstrak
Pengembangan produk harus memikirkan detail baik pemilihan material, proses produksi, proses perkitan, sampai pada bagaimana perawatan produk setelah diterima konsumen. Semua menjai satu proses panjang menuju keberlanjutan hidup produk. Pada prinsipnya semakin sederhana material, menggunakan finishing non toxic, sistem sambungan sederhana, menggunakan kemasan yang berbahan ramah lingkungan, ukuran kemasan diperkecil. Dengan proses yang disederhanakan, mesin produksi yang digunakan bisa lebih ditekan, artinya semakin sedikit mesin produksi yang digunakan, energi untuk menggerakkan mesin bisa lebih hemat. Semakin sedikit jumlah material yang digunakan semakin sedikit limbah paska umur hidup produk berakhir. Pemilihan bahan sangat berpengaruh pada proses daur ulang, guna ulang produk. Dengan metode desain yang memperhitungkan perakitan(DfA), manufaktur (DfM), perawatan (DfMaintanance) maka sebuah produk akan bertahan lebih lama umur hidupnya (Sustainable Product Development-SPD), proses produksi lebih disingkat, energi lebih hemat, kemasan bisa lebih ringkas.
\end{abstract}

Kata Kunci : Desain, DfA,DfM,DfMa, SpD

\section{a. Latar Belakang}

Pengembangan produk dan keberlanjutannya adalah kombinasi dan kondisi yang penting mulai dari tahapan rancangan, pemilihan bahan baku, tipikal produk, sampah produk. Banyaknya komponen yang dilibatkan mulai awal produk dikembangkan, proses produksi, pemasaran, sampai pengolahan sampah sisa produksi. Karena banyaknya hal yang dilibatkan dan setiap industri memilki karakteristik yang berbeda maka diperlukan metodologi yang tepat untuk mengembangkan dan menerapkan produk yang lebih berkelanjutan. Terdapat beberapa definisi yang terkait dengan Pengembangan Produk Berkelanjutan (Sustainable Product Development). Definisi awal dikeluarkan oleh Worlds Commission on Environment and Development's pada dasarnya produk berkelanjutan adalah segala jenis produk yang diproduksi saat ini namun pemanfaatannya harus selalu berkaitan dengan kebutuhan di masa depan. Berdasarkan penelitian sebelumnya metode SPD terbukti memberikan kontribusi besar pada keberlanjutan umur produk, dan memberikan kemungkinan untuk sebuah produk memiliki umur yang lebih panjang dengan melakukan berbagai treatment seperti recycle dan reuse. Dengan demikian dengan perancangan awal pada proses SPD mampu menghemat kebutuhan bahan baku dan proses, sehingga secara keseluruhan dapat menghemat biaya-biaya pada industri manufaktur. (Rusdiyantoro, 2011).

Desain produk pada industri furnitur memiliki dampak besar pada keberlanjutan produk, dimana IKM harus memiliki strategi dan kontrol pada setiap tahapan proses produksi menggunakan teknologi yang mendukung produksi bersih.Berdasarkan situasi tersebut, penelitian ini akan memberikan sebuah metode pada pengembangan furnitur berkelanjutan, dimana faktor lingkungan menjadi perhatian utama sejak ide desain sampai produk final. Penelitian ini akan mencari konsep SPD melalui penggabungan metode DfM (Design for Maintanance), DfA (Design for Assembly), dan DfD (Design for Disassembly).Tujuan dalam usul penelitian ini adalah : perancangan metode Sustanable Product Development berbasis Design for Assembly, Design for Dissasemly, Design for Maintanance dalam untuk mencapai produksi bersih pada industri furnitur berbahan logam. 


\section{Metode Penelitian}

Untuk mencapai tujuan penelitian, maka tahapan kegiatan yang dilakukan adalah Studi literatur tinjauan penelitian terdahulu, rancangan penelitian : a. Kerangka penelitian, b. Penelitian pendahuluan, c. Kriteria desain, d. Persiapan penelitian., pelaksanaan penelitian, pengolahan data : a. Pengukuran dan klastering jenis serta jumlah bahan baku utama, pendukung, bahan baku kemasan b. Pengamatan proses sejak proses assembly (DfA) penggabungan setiap komponen, proses disassembly (DfD) penguraian komponen. Pengamatan proses dan penjadwalan maintanance (DfM) c. Pembuatan Metode Eco Desain pada proses DfA dengan rancangan bantalan pengunci untuk mengurangi scap cetakan, dan perbaikan posisi operator pada bagian asembling pada proses DfD memperbaiki proses kerja di area bongkar pasang, mengurangi jenis dan tipe komponen bahan produk, dan DfM melakukan perbaikan penjadwalan perawatan mesin. Pembuatan prototipe kursi elephant dengan minimum komponen, penyederhanaan sistem sambungan dan mengurangi variasi bahan baku.

Judul Penelitian:

Metodologi Eco Desain Yang Digunakan Untuk Pengembangan Produk Furniture Berbasis Logam Secara Berkelanjutan

Tujuan Penelitian:

perancangan metode Sustanable Product Development berbasis Design for Assembly, Design for Dissasemly,

Design for Maintanance dalam untuk mencapai produksi bersih pada industri furnitur berbahan logam.

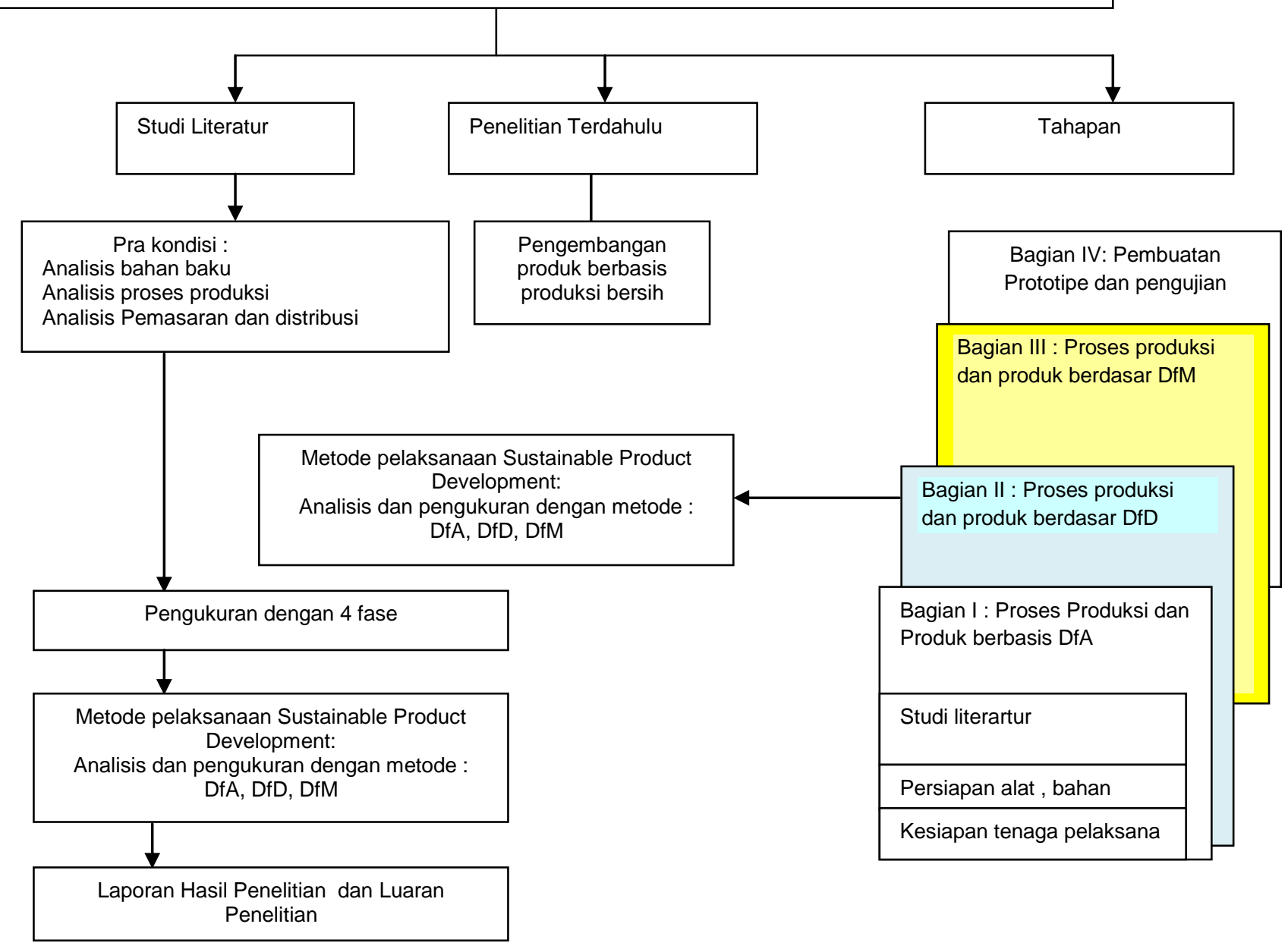

Gambar 1. Metode Pelaksanaan Penelitian 
Mengurangi dampak lingkungan karena kesalahan pemilihan material, proses produksi, limbah

Dampak lingkungan karena limbah bahan baku

\begin{tabular}{|c|c|}
\hline \multicolumn{2}{|c|}{ FASE 1.} \\
\hline \multicolumn{2}{|c|}{ Tdentifikasi konsumen } \\
\hline \multicolumn{2}{|c|}{ Definisi Permasalahan } \\
\hline & Penggalian Kebutuhan \\
\hline & $\begin{array}{l}\text { Permasalahan Karakteristik } \\
\text { Desain }\end{array}$ \\
\hline \multicolumn{2}{|c|}{$\begin{array}{l}\text { Sistem Karakteristik : PENGGUNA- } \\
\text { ALAT-PENGERJAAN-LINGKUNGAN } \\
\text { Tujuan }\end{array}$} \\
\hline & Kebutuhan \\
\hline- & Batasan \\
\hline Biaya & Program Kerja \\
\hline
\end{tabular}

Biaya

\section{FASE 2}

State of Art - Analisis Kemiripan

Analisis Proses Produksi

Manufaktur dan proses transformasi

Jalur perakitan (assembly line)

Aspek administrasi dan teknis

Jumlah dan diversivikasi jenis komponen (DfA)

Material mentah dan bahan lainnya

Products lifecycle dan bagian-bagiannya

Analisis data historis tentang kemiripan bahan dan proses

Analisis struktur kemiripan

Jumlah komponen

Sistem produksi

Struktur komponen

Kuantitas dan standar komponen yang terlibat

Material mentah dan bahan lainnya

Products lifecycle dan bagian-bagiannya

Sintesis

Pengaturan parameter prosedur

Review Tujuan

- Kebutuhan (requirement)

Alternatif Awal

Batasan (Restriction)

- $\quad$ Gambar dan Model 3 Dimensi

Proyeksi parameter review

Alternatif Pilihan

Gambar dan Model 3 Dimensi

Proyeksi parameter review

Matrik keputusan (QFD)

Gambar Teknik

- $\quad$ Gambar Lay Out, Group, Sambungan

Perspektif gambar urai untuk proses asembli

Diagram asembli

Spesifikasi

Rekomendasi ergonomis

\section{Congcurrent Engineering}

- $\quad$ Mengurangi waktu produksi

- $\quad$ Mengurangi kesalahan produksi

- Mengurangi biaya-biaya

Pengembangan fungsi baru

Pengujian dan validasi proses manufaktur

Sustainable Development dan Aplikasi menyeluruh DfE

Gelombang Eco Desain

- Pemilihan material ramah lingkungan

- Sistem transportasi

- Sistem pengemasan

- Konsumsi energi, air dan material tambahan lain

- Product lifecycle

- Reuse, recycle, reprocessing komponen

Variabel-variabel optimasi produk

- Pengurangan konsumsi energi

- Proses ulang pada beberapa bagian sub produk

- Minimalisasi limbah yang dihasilkan DfA

- Pengurangan jumlah variasi produk

- Pengurangan tahapan proses

- Optimasi material handling

- Kemudahan proses penyambungan antar komponen
Analisis Fungs

Mekanisme

Fleksibilitas

Ketahanan

Finishing

Recycle produk/komponen setelah produk

rusak

Analisis Ergonomi Pada Kemiripan Fungsi

Kegunaan

Keamanan

Transport

Maintanance dan Perbaikan

Antrhopometry

Biomechanics

Aktivitas Kerja

Kognisi

Proses perakitan (assembly) dan proses

pembongkaran (deassembly) selama proses (DfA \& DfD)

- $\quad$ Konsumsi energi selama produksi

- $\quad$ Proses generate limbah

Analisis Morfologi Produk

Bentuk

Estetika

Teknik sambungan

Teknik kemasan

Dampak kemasan terhadap lingkungan

Analisis Pasar

Iklan

Pemasaran

Informasi pengolahan produk pada proses

lifecycle

Alternatif bahan baku

Perbaikan dan perubahan proses produksi

Sistem mekanik dan elektronik

Dampak lingkungan karena bahan baku

Dampak lingkungan karena proses manufaktur elektronik

Dampak lingkungan karena sistem mekanik dan

Analisis Data
Analisis Teknis

\section{Gambar 1. Metode Pelaksanaan Penelitian}




\section{Hasil Dan Pembahasan}

\section{Pangsa Pasar dan Pertumbuhan Perminataan Kursi Lipat Di Indonesia}

Sesuai dengan statistik yang dikeluarkan oleh Dewan Ekonomi dan Sosial Perserikatan BangsaBangsa, populasi perkotaan di Indonesia akan tumbuh sebesar $13 \%$ selama periode lima tahun dari 2010 sampai tahun 2015. Selain itu, Bank Dunia juga memperkirakan jumlah konsumen kelas menengah di Indonesia akan melebihi 150 juta konsumen pada tahun 2014 (sumber : The World Bank, tahun 2014). Lembaga riset AC Nielsen memperkirakan, masyarakat kelas menengah di Asia Tenggara akan tumbuh $110,5 \%$ dari 190 juta orang pada 2012 menjadi 400 juta orang pada 2020 dengan Indonesia sebagai kontributor pertumbuhan tertinggi. Pertumbuhan masyarakat kelas menengah Indonesia dalam kurun 2012-2020 diperkirakan mencapai 174\%. (sumber : Nielsen, tahun 2014)

Tabel 1. Pertumbuhan Industri Kursi di PT.X Indonesia.

\begin{tabular}{|c|c|c|c|c|c|c|c|c|c|c|c|c|c|c|c|}
\hline KATEGORI & \multicolumn{3}{|c|}{2009} & \multicolumn{3}{|c|}{2010} & \multicolumn{3}{|c|}{2011} & \multicolumn{3}{|c|}{2012} & \multicolumn{3}{|c|}{2013} \\
\hline PRODUK & $\begin{array}{l}\text { Juta } \\
\text { Rp }\end{array}$ & $\Delta$ & $\Delta \%$ & $\begin{array}{l}\text { Juta } \\
\text { Rp }\end{array}$ & $\Delta$ & $\Delta \%$ & $\begin{array}{c}\text { Juta } \\
\text { Rp }\end{array}$ & $\Delta$ & $\Delta \%$ & $\begin{array}{c}\text { Juta } \\
\text { Rp }\end{array}$ & $\Delta$ & $\Delta \%$ & $\begin{array}{c}\text { Juta } \\
\mathrm{Rp}\end{array}$ & $\Delta$ & $\Delta \%$ \\
\hline $\begin{array}{c}\begin{array}{c}\text { Folding } \\
\text { chair }\end{array} \\
\end{array}$ & 62,314 & $(9,117)$ & $\begin{array}{c}- \\
14,63 \%\end{array}$ & 66,668 & 4,660 & $6,99 \%$ & 71,248 & 4.895 & $6,87 \%$ & 66,605 & $(4,643)$ & $-7 \%$ & 68,122 & 1,517 & $2,23 \%$ \\
\hline $\begin{array}{c}\text { Folding } \\
\text { chair+memo }\end{array}$ & 55,298 & 8,532 & $15,43 \%$ & 62,494 & 8,130 & $13,01 \%$ & 63,349 & 868 & $1,37 \%$ & 72,319 & 8,970 & $12 \%$ & 64,977 & (7342) & $11,30 \%$ \\
\hline $\begin{array}{c}\text { Hotel \& } \\
\text { banguet } \\
\text { resto }\end{array}$ & 40,666 & 4,624 & $11,37 \%$ & 49,511 & 10,650 & $21,51 \%$ & 50,541 & 1,051 & $2,08 \%$ & 53,644 & 3,103 & $6 \%$ & 74,954 & 21,310 & $28,43 \%$ \\
\hline $\begin{array}{c}\text { School } \\
\text { education }\end{array}$ & 27,375 & 1,856 & $6,78 \%$ & 18,884 & $(5,858)$ & $\begin{array}{c}-\overline{3} \\
31,02 \%\end{array}$ & 23,909 & 6,362 & $26,61 \%$ & 32,153 & 8,244 & $26 \%$ & 40,519 & 8,366 & $20,65 \%$ \\
\hline $\begin{array}{c}\text { Working \& } \\
\text { meeting }\end{array}$ & 20,319 & 264 & $1,30 \%$ & 23,340 & 3,471 & $14,87 \%$ & 23,944 & 620 & $2,59 \%$ & 23,792 & (152) & $-1 \%$ & 23,984 & 192 & $0,80 \%$ \\
\hline $\begin{array}{c}\text { Hospital } \\
\text { items }\end{array}$ & 4,035 & 1,082 & $26,81 \%$ & 3,146 & $(693)$ & $22,03 \%$ & 6,444 & 6,755 & $104,83 \%$ & 4,990 & $(1,454)$ & $29 \%$ & 15,573 & 10,583 & $67,96 \%$ \\
\hline & 210,007 & 98,829 & $47,06 \%$ & 224,043 & 7,461 & $3,33 \%$ & 239,435 & 345,624 & $144,35 \%$ & 253,503 & 14,068 & $6 \%$ & 288,129 & 34,626 & $12,02 \%$ \\
\hline
\end{tabular}

Sumber : Laporan tahunan PT X Indonesia 2014

\section{Kemiripan Produk Dan Sistem Asemblinya (DATA DFA)}

Kebutuhan pengguna kursi lipat atau konsumen dibagi menjadi beberapa faktor diantarnya:

1. Mudah untuk disimpan

2. Mudah dibersihkan

3. Struktur sambungan yang kuat

4. Struktur bahan yang kuat menahan beban pengguna

5. Konsetruksi bahan pelapis kuat tidak mudah mengelupas

6. Mudah untuk perawatan, dan tahan lama.

Sedangkan kebutuhan bagi produsen kursi lipat dibagi menjadi beberapa faktor diantaranya :

1. Kecepatan proses produksi

2. Teknik sambungan yang lebih sederhana sehingga mengurangi langkah proses produksi dan otomatis bisa mengurangi nilai investasi peralatan produksi.

3. Konstruksi kuat

4. Teknik lipat sederhana dan mengurangi volume kemasan

Setiap produk kursi lipat memiliki kemiripan terutama pada bagian kaki, dudukan, sandaran dan teknik kuncian sambungan. Berikut adalah beberapa tipe kursi lipat yang menjadi trend setter dipasar Indonesia. 
Tabel 2. Beberapa kemiripan produk kursi lipat

\begin{tabular}{|c|c|c|c|c|c|c|}
\hline No & $\begin{array}{l}\text { Variabel } \\
\text { Kemiripan }\end{array}$ & $\begin{array}{l}\text { Tipe PT. X } \\
\text { Indonesia } \\
\text { cosmo } 541\end{array}$ & $\begin{array}{l}\text { Tipe PT. X } \\
\text { Indonesia } \\
\text { cosmo } 951\end{array}$ & $\begin{array}{l}\text { Tipe PT. X } \\
\text { Indonesia } \\
\text { daishogun }\end{array}$ & $\begin{array}{c}\text { Tipe PT. X } \\
\text { Indonesia } 441 \text { / } \\
442\end{array}$ & $\begin{array}{l}\text { FLD OMC } \\
\text { design }\end{array}$ \\
\hline \multirow{2}{*}{1} & \multirow{2}{*}{$\begin{array}{l}\text { Material } \\
\text { Rangka }\end{array}$} & $\begin{array}{c}\text { Pipa hollow } \\
\text { steel }\end{array}$ & $\begin{array}{c}\text { Pipa hollow } \\
\text { steel }\end{array}$ & $\begin{array}{c}\text { Pipa hollows } \\
\text { steel }\end{array}$ & $\begin{array}{c}\text { Pipa hollow } \\
\text { steel }\end{array}$ & Stainless bars \\
\hline & & $\begin{array}{l}\text { Spesifikasi } \\
\text { AISI } 1020\end{array}$ & $\begin{array}{l}\text { Spesifikasi } \\
\text { AISI } 1020\end{array}$ & $\begin{array}{l}\text { Spesifikasi } \\
\text { AISI } 1020\end{array}$ & $\begin{array}{l}\text { Spesifikasi } \\
\text { AISI } 1020\end{array}$ & - \\
\hline 2 & Material plat & $\begin{array}{c}\text { Optimum } \\
\text { PLATE SPCC- } \\
\text { SB }\end{array}$ & $\begin{array}{c}\text { Optimum } \\
\text { PLATE SPCC- } \\
\text { SB }\end{array}$ & $\begin{array}{c}\text { Optimum } \\
\text { PLATE SPCC- } \\
\text { SB }\end{array}$ & $\begin{array}{c}\text { Optimum } \\
\text { PLATE SPCC- } \\
\text { SB }\end{array}$ & $\begin{array}{c}\text { Optimum } \\
\text { PLATE SPCC- } \\
\text { SB }\end{array}$ \\
\hline 3 & Bahan lapis & PVC vinyl & PVC vinyl & PVC vinyl & PVC vinyl & Non pelapis \\
\hline 4 & Sistem kunci & $\begin{array}{c}2 \text { kuncian } \\
\text { dengan } 3 \\
\text { sekrup }\end{array}$ & $\begin{array}{l}2 \text { kuncian } \\
\text { dengan } 3 \\
\text { sekrup }\end{array}$ & $\begin{array}{l}2 \text { kuncian } \\
\text { dengan } 3 \\
\text { sekrup }\end{array}$ & $\begin{array}{l}2 \text { kuncian } \\
\text { dengan } 3 \\
\text { sekrup }\end{array}$ & $\begin{array}{l}1 \text { kuncian non } \\
\text { sekrup }\end{array}$ \\
\hline 5 & $\begin{array}{c}\text { Screw } \\
\text { fastermer }\end{array}$ & 3 & 3 & 3 & 3 & 1 \\
\hline 6 & $\begin{array}{c}\text { Finishing } \\
\text { material }\end{array}$ & Chrom plated & Chrom plated & Chrom plated & Chrom plated & Non finisihing \\
\hline 7 & $\begin{array}{l}\text { Nomor paten } \\
\text { yang mirip }\end{array}$ & $\begin{array}{c}\text { US } 6,543,842 \\
\text { B2 }\end{array}$ & US $477,470 \mathrm{~S}$ & $\begin{array}{l}\text { US } 6,543,842 \\
\text { B2 }\end{array}$ & $\begin{array}{l}\text { US } 6,543,842 \\
\text { B2 }\end{array}$ & $\begin{array}{c}\text { US 8,721,003 } \\
\text { B2 }\end{array}$ \\
\hline 8 & $\begin{array}{c}\text { Tahun ,ulai } \\
\text { berlaku }\end{array}$ & Apr. 8,2003 & Jul. 22, 2003 & Apr. 8,2003 & Apr. 8, 2003 & May. 13, 2014 \\
\hline 9 & $\begin{array}{l}\text { Pembiayaan } \\
\text { paten }\end{array}$ & Berbayar & Berbayar & Berbayar & Berbayar & Berbayar \\
\hline 10 & $\begin{array}{c}\text { Berat produk } \\
\text { total }\end{array}$ & $4,3 \mathrm{Kg}$ & $4,2 \mathrm{Kg}$ & $4,1 \mathrm{Kg}$ & $4,1 \mathrm{Kg}$ & $3,1 \mathrm{Kg}$ \\
\hline
\end{tabular}

Data Proses Produksi Di PT . X Indonesia (Data DFM)

Perencanaan produksi merupakan salah satu aspek penting dalam manajemen produksi PT.X Indonesia selaku produsen furnitur. Perencanaan yang baik dapat menciptakan efisiensi yang tinggi yang dapat meningkatkan kinerja keuangan PT.X Indonesia. Jika suatu perusahaan memiliki sistem perencanaan produksi yang tidak baik, maka akan dapat menimbulkan kondisi yang tidak efisien yang akan berdampak pada kenaikan biaya yang tinggi, yang dapat menghambat dan mengurangi laju kinerja keuangan PT.X Indonesia. 


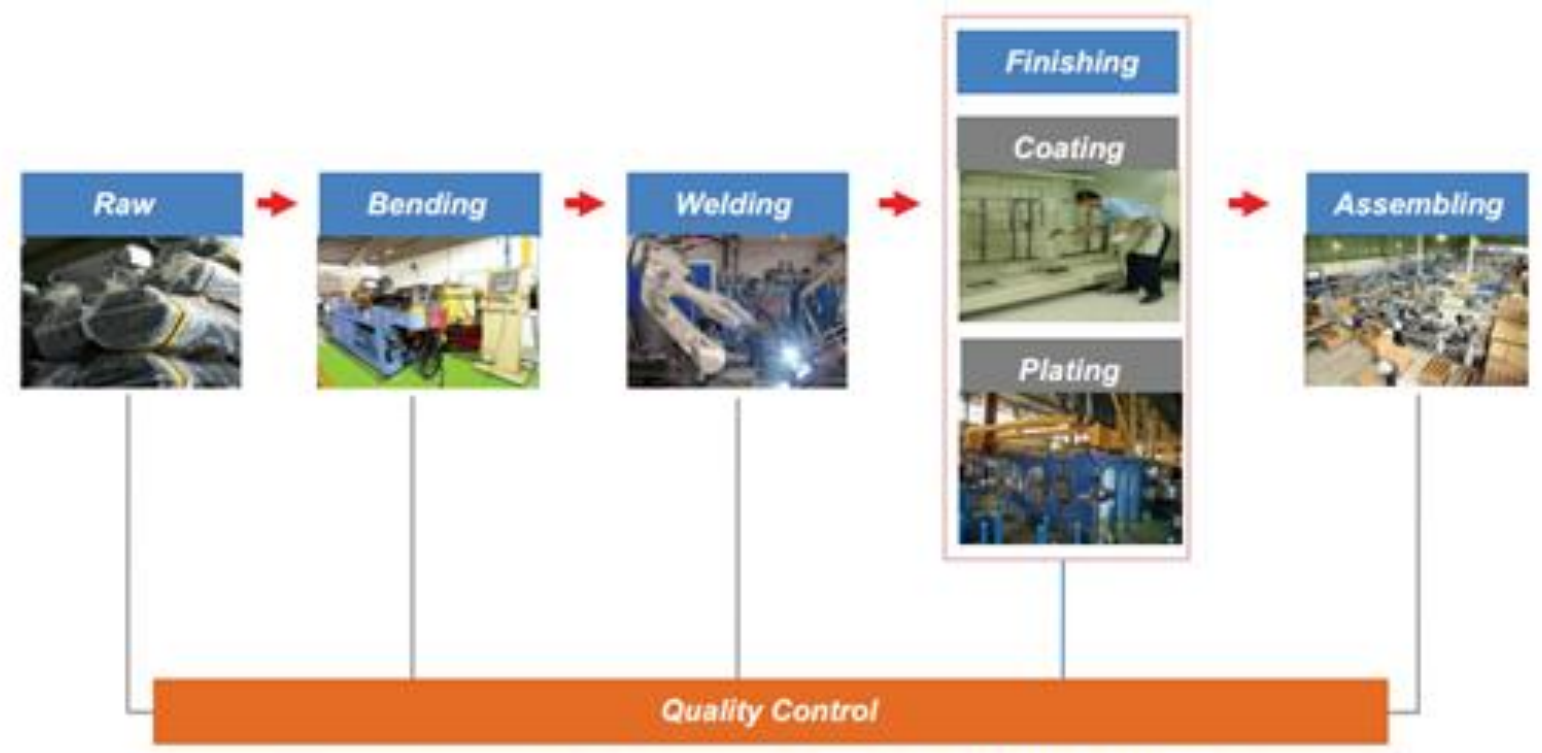

Gambar 3. Proses Produksi Kursi Lipat PT. X Indonesia

Secara umum produk produk yang sama oleh PT.X Indonesia akan diproduksi secara berurutan untuk memudahkan proses serta mengurangi waktu untuk setting mesin. Prinsip kerja produksi PT.X Indonesia menganut prinsip $3 \mathrm{~S}$ ( Seiri - Bereskan- Bedakan antara yang perlu dan yang tidak perlu dan buanglah yang tidak perlu, Seiton - Simpan dengan rapi - Barang harus disimpan dengan teratur sehingga siap pakai bila diperlukan, Seiso - Bersihkan -Pelihara tempat kerja supaya tetap bersih) dan prinsip zero defect pada proses produksi untuk mendapatkan efisiensi produksi yang tinggi. Persiapan raw material seperti pipa, plate, busa, cover, cartoon box dan komponen lainnya dilakukan sesuai dengan rencana produksi yang sudah dibuat.

Berdasarkan pengamatan di lapangan, komponen kursi lipat logam terdiri dari lima bagian utama yaitu bagian kaki, bagian dudukan, bagian sandaran, detail sambungan dan aksesoris. Langkah produksi awal untuk pembuatan kaki bahan pipa ditekuk dan di bor pada beberapa bagian untuk menempatkan sekrub sebagai komponen sambungan. Bagian dudukan proses diawali dengan plat yang dipotong sesuai pola, selanjutnya di press untuk membentuk struktur monocoque, dilanjutkan dengan memberikan lubang pada bagian tertentu untuk menempatkan sekrub sebagai sambungan.

Untuk komponen sandaran, proses produksi hampir sama dengan proses produksi pada bagian dudukan, namun pada bagian sandaran proses press dilakukan 2 kali yaitu untuk membentuk struktur monococue dan membentuk lekukan sandaran disesuaikan dengan ergonomis manusia.

Tabel 3. waktu operasi rata-rata pembuatan satu kursi lipat

\begin{tabular}{lll}
\hline No & Proses operasi & $\begin{array}{l}\text { Waktu siklus } \\
\text { rata-rata } \\
\text { (menit) }\end{array}$ \\
\hline 1 & Proses potong pipa kaki ke-1 & 1.12 \\
2 & Proses tekuk U ke-1 & 1.07 \\
3 & Proses tekuk U ke-2 & 1.20 \\
4 & Proses potong pipa kaki ke-2 & 1.10 \\
5 & Proses tekuk U ke-1 & 1.07 \\
6 & Proses tekuk U ke-2 & 1.10 \\
7 & Proses potong pipa sandaran & 1.12
\end{tabular}




\begin{tabular}{lll}
8 & Proses tekuk U ke-1 & 1.07 \\
9 & Proses tekuk U ke-2 & 1.20 \\
10 & Proses potong plat dudukan & 2.10 \\
12 & Proses mal pengepon dudukan & 2.55 \\
13 & Proses pelubangan plat dudukan & 2.45 \\
14 & Proses potong plat sandaran & 2.55 \\
15 & Proses mal pengepon sandaran & 2.67 \\
16 & Proses pelubangan plat sandaran & 2.34 \\
17 & Proses finishing (pencelupan chrom) & 10.45 \\
& Proses finishing (powder coating) & 25.21 \\
18 & Proses mal tripleks dudukan & 2.30 \\
19 & Proses potong mal tripleks dudukan & 2.25 \\
20 & Proses potong busa dudukan & 1.70 \\
21 & Proses pengeleman pelapis (plus waktu tunggu kering & 30.55 \\
22 & pelapis dan lem) & \\
& Proses asembly body (plus waktu perakitan dengan & 35.21 \\
23 & teknik pemasangan sekrup) & 20.15 \\
24 & Proses asembly dudukan dan sandaran & 3.45 \\
25 & Proses pengepakan inner shipper & 20.1 \\
Total waktu per kursi & 180.83 menit \\
\hline
\end{tabular}

Selama proses produksi kursi lipat di PT.X, mesin-mesin yang digunakan, mesin ini dibagi menjadi beberapa proses utama. Dan proses pendukung. Data peralatan dan mesin dalam membuat kursi lipat

Tabel 4. Mesin yang digunakan di PT.X

\begin{tabular}{ll}
\hline lokasi stasiun kerja & nama mesin \\
\hline Konstruksi multi bending & hoist \\
inclinable press 6 ton & double bending \\
bending horizontal & pipe bender chiwork \\
bending horizontal lang German & double side bending 2 \\
press vertical & inclinable press 16 ton \\
shringking machine & Cnc bending \\
mesin press \\
mesinbor \\
rivet setter frame 7 \\
air dryer \\
rivet setter frame 1 \\
Assembly eksport & air compressor \\
eight multi spot welder \\
inclinable press 1 \\
shearing machine \\
double bending \\
multi spot welder \\
rivet setter frame \\
box machine \\
double piercing cosmo \\
rivet setter frame 8
\end{tabular}


konstruki multi gas

pengecatan

Nailing multy dan assembling multi auto co welder

las listrik

powder spray dan booth

pre treadment

oven drying

continous s pray

spray glue dan booth

pneumatic press dan air neller

tangki proses hot water rinsing

tangki proses rinse chrome 2 double tank

tangki prose drug out chrome

tangki proses electro cleaner

tangki proses soak clean

tangki proses rinse pickiling

tangki proses acid pickiling

tangki proses acid dipping

tangki proses rinse nickle

tangki proses drag out nickle

tangki proses nickle

tangki proses slurry

tangki proses electro clean circulation and pump

dozing pump

exhaust fan

cooling tower

Dari data bahan baku kursi lipat di PT X Indonesia, bahan baku utama adalah pipa, plat bahan dudukan dan sandaran serta pastic vinyl sebagai pelapis. Namun dengan ketiga bahan baku utama, proses produksi menjadi panjang karena sambungan dari kursi-kursi lipat yang diproduksi oleh PT.X masih menggunakan sambungan las, sekrub dan rivet.

Dalam rancangan awal kursi dari PT $\mathrm{X}$ dapat dibagi menjadi beberapa fungsi sistem

Tabel 5. Fungsi Sistem Kursi Lipat

\begin{tabular}{|c|c|c|c|c|c|c|c|c|c|c|}
\hline \multirow[b]{2}{*}{ Fungsi Sistem } & \multirow[b]{2}{*}{ 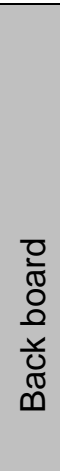 } & \multirow[b]{2}{*}{$\begin{array}{l}\bar{\pi} \\
\text { ల } \\
\text { ஸ }\end{array}$} & \multirow[b]{2}{*}{ 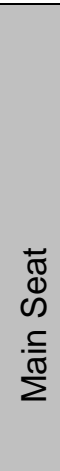 } & \multicolumn{4}{|c|}{ Elemen Sistem } & \multicolumn{3}{|c|}{$\begin{array}{c}\text { Luar } \\
\text { Sistem }\end{array}$} \\
\hline & & & & 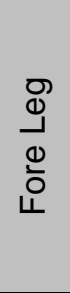 & 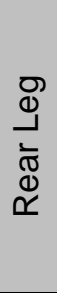 & 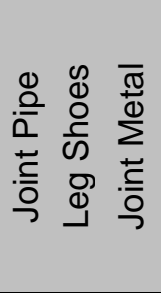 & 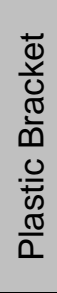 & 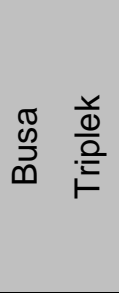 & 㞼 & 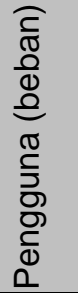 \\
\hline 1. Melindungi busa dan triplek & $\mathrm{X}$ & & $\mathrm{X}$ & & & & & & $\mathrm{X}$ & $\mathrm{X}$ \\
\hline 2. Menahan beban sandaran punggung & $\mathrm{x}$ & & & & & & & & & $\mathrm{X}$ \\
\hline 3. Menutup busa & & $\mathrm{X}$ & & & & & & $\mathrm{X}$ & & \\
\hline 4. Melindungi main seat & & $\mathrm{X}$ & $\mathrm{X}$ & & & & & & & \\
\hline 5. Menahan beban berat badan & & $x$ & $\mathrm{x}$ & & & & & & & $X$ \\
\hline 6. Menyangga beban & & & $\mathrm{X}$ & $\mathrm{X}$ & $\mathrm{X}$ & & & & $\mathrm{X}$ & \\
\hline 7. Menyeimbangkan kursi lipat & & & $\mathrm{X}$ & $\mathrm{X}$ & & $\mathrm{X} \times$ & & & $\mathrm{X}$ & \\
\hline $\begin{array}{l}\text { 8. Mendistribusikan gaya akibat beban pada } \\
\text { fore leg dan rear leg }\end{array}$ & & & $\mathrm{X}$ & $\mathrm{X}$ & $\mathrm{X}$ & & & & $\mathrm{x}$ & \\
\hline 9. Menahan beban pijakan kaki & & & & & $\mathrm{X}$ & & & & $\mathrm{X}$ & \\
\hline 10. Menumpu beban & & & & & & $\mathrm{X}$ & & & $\mathrm{X}$ & \\
\hline
\end{tabular}


11. Melindungi fore leg dan rear leg dari air atau kotoran

12. Menghubungkan fore leg dan rear leg

13. Memudahkan putaran pada saat

membuka/melipat kursi

14. Meneruskan beban pada fore leg dan rear leg

15. Mengkaitkan dengan kursi yang lain supaya tertata rapi

16. Menumpu beban pada fore leg

17 Melindungi rear leg dari tumpuan beban

17. fore leg

$\begin{array}{lll}X & X\end{array}$

18. Memberikan kenyamanan pada saat

18. duduk

19. Merekatkan seat dan busa

$x \quad x$

$X$

$x$

$X$

$\begin{array}{llll}X & X & X\end{array}$

$x$

$\begin{array}{lll}x & x\end{array}$

$x \quad x \quad x$

$\begin{array}{lll}x & x \\ x & x & \end{array}$

Data Kemasan Yang Digunakan Untuk Produk Kursi Lipat

Sebelum menentukan jenis kemasan yang digunakan. Desainer harus memilih alternatif material yang digunakan yaitu:

1. Kurangi variasi jenis material yang digunakan

2. Kurangi jumlah material termasuk berat dan ukuran kemasan

3. Gunakan material yang memiliki dampak minimum pada lingkungan

4. Gunakan bahan yang sudah didaur ulang

5. Gunakan banyan yang diperbaharui

6. Tidak mengandung lead, cadmium, mercury, chromium

7. Bisa didaur ulang dan memiliki kemampuan untuk di-reuse, maerial recovery, energy recovery dan organic recovery (ISO 11469)

Ukuran kemasan sangat menentukan ukuran pengiriman dalam kontainer. Sebagai perbandingan produk setelah rancangan dan sebelum perancangan. Dalam pengembangan produk kursi lipat ada beberapa yang unggul dibanding produk sebelumnya.

1. Kursi lipat tidak menggunakan banyak bahan yang berbeda

2. Kursi menggunakan sistem sambungan 2 tipe saja yaitu las dan engsel tunggal

3. Kursi menggunakan kain kanvas sebagai dudukan bukan tripleks dilapis spons dan bahan pelapis vinil.

4. Kain kanvas bisa dicuci (dilepas)

5. Ukuran lipat lebih kecil sehingga mampu mengurangi ukuran kemasan dalam kontainer.

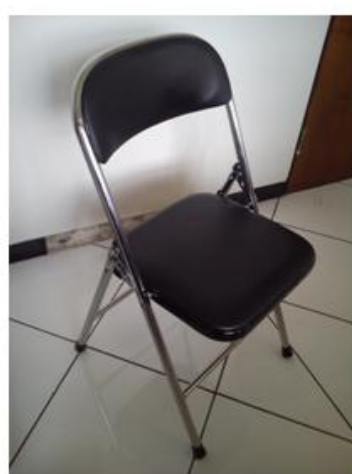

(a)

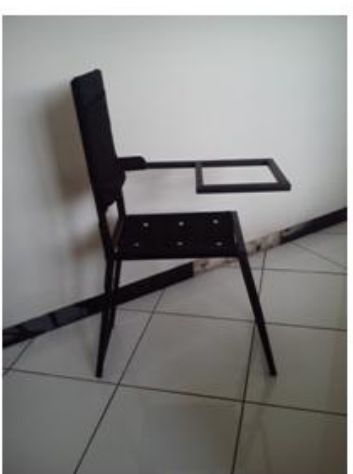

(b)

Gambar 4.Kursi lipat produksi PT.X (produk a), dan kursi lipat desain yang diusulkan (b) Ukuran hasil pelipatan kursi lipat B lebih jecil dari pada kursi A, dengan demikin, volume karton yang digunakan sebagai kemasan bisa dikurangi, dan secara total pengemasan dalam pengiriman bisa memuat unit lebih banyak, dan menghemat material kemasan, energi bahan bakar dalam pengiriman , dan menghemat biaya secara keseluruhan. 


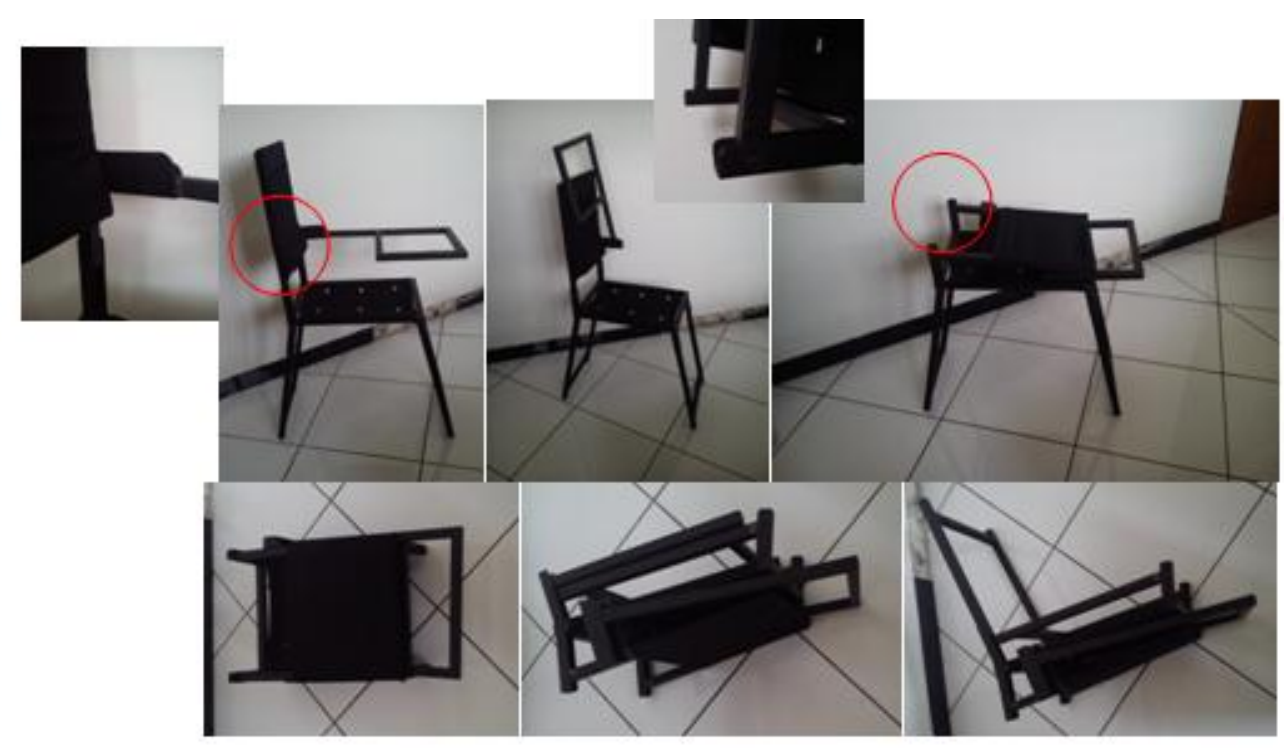

Gambar 5 Proses pelipatan kursi desain usulan

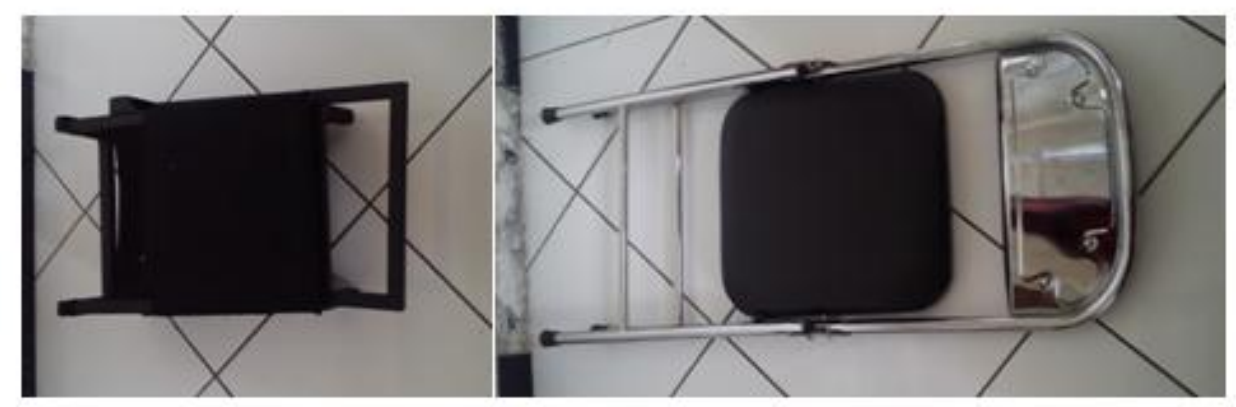

Gambar 6. Posisi hasil lipatan kursi yang diusulkan dan kursi yang sudah ada

\begin{tabular}{|c|c|c|}
\hline Alternatif produk & Kursi produk PT.X & Kursi Lipat Yang Diusulkan \\
\hline Variasi Material & 10 variasi & 3 variasi \\
\hline $\begin{array}{l}\text { Meter Kubik material kemasan } \\
\text { yang dibutuhkan }\end{array}$ & $1 \times 0.65 \times 0.08=0.52 \mathrm{~m} 2$ & $0.6 \times 0.6 \times 0.12=0.0432 \mathrm{~m} 2$ \\
\hline Bahan & Lebih dari 10 variasi & $\begin{array}{l}\text { Sedikit variasi mengurangi } \\
\text { resiko pada lingkungan }\end{array}$ \\
\hline Bahan yang diperbarui & $\begin{array}{l}\text { Spons dan vinil tidak bisa } \\
\text { diperbaharui }\end{array}$ & Bahan kanvas bisa diperbaharui \\
\hline $\begin{array}{l}\text { Finishing tidak mengandung } \\
\text { lead, cadmium, mercury dan } \\
\text { chromium }\end{array}$ & $\begin{array}{l}\text { Lead, cadmium, mercury, } \\
\text { chrom }\end{array}$ & lead \\
\hline Daur Ulang & rangka & Bahan rangka dan pelapis \\
\hline
\end{tabular}

\section{Kesimpulan dan Saran}

Kesimpulan

1. Produk furniture yang lebih ramah lingkungan sangat dibutuhkan karena perkembangan furniture yang luar biasa dari tahun ke tahun.

2. Penggunaan bahan baku untuk kursi lipat perlu dievaluasi sebab produk kursi lipat yang ada menggunakan lebih dari 10 variasi material. Hanya 1 material yaitu logam baik stainsless atau lainnya yang bisa di daur ulang. 
3. Penggunakan sistem sambungan yang bervariasi membutuhkan banyak mesin. Artinya semakin banyak mesin yang digunakan, semakin besar energi yang dibutuhkan untuk menjalankan mesin tersebut.

4. Sambungan sebaiknya disederhanakan, dengan tujuan mengurangi proses produksi, sehingga mesin yang digunakan juga berkurang. Otomaatis energi yang dibutuhkan lebih ringan.

5. Proses pelipatan sangat berpengaruh pada hasil lipatan kursi. Semakin kecil lipatan kursi, artinya kemasan yang dibutuhkan semakin berkurang. Dengan berkurangnya bahan baku kemasan (umumnya terbuat dari karton), maka jumlah bahan baku karton (serat pohon) bisa ditekan.

6. Seluruh proses sangat dipengaruhi dari awal desain produk.

Saran

1. Rancangan kursi yang diusulkan masih bisa dikembangkan terutama untuk kekuatan sambungan.

2. Untuk penelitian selanjutnya bisa diupayakan penelitian efisiensi biaya lebih detail dari rancangan yang diusulkan.

\section{Ucapan Terimakasih}

Penelitian ini didanai oleh Hibah Penelitian Universitas PGRI Adi Buana Surabaya, Pendaan tahun 2015.

\section{Daftar Pustaka}

Kano, N., Seraku, K., Takahashi, F., \& Tsuji, S. (1984). Attractive quality and must-be quality. The Journal of the Japanese Society for Quality Control, pp. 39 -48.

Lee,Y., Sheu,L., Tsou,Y., (2008). Quality Function Deployment Implementation Based on Fuzzy Kano Model : An Application in PLM System, Computers \& Industrial Engineering 2008.

Rusdiyantoro, 2010, Pengembangan Model Integrasi Sustainable Product Development (SPD) Untuk Menjamin Keberlanjutan Produk, Hibah Adi Buana DIPA 2010

Rusdiyantoro, 2010, Perancangan Rombong Dan Tenda Pedagang Kaki Lima Penjual Makanan Yang Estetis Dan Ergonomis Dengan Metode Kano-QFD (Studi Kasus PkI Di Alun-Alun Sidoarjo) Surat Perjanjian Pelaksanaan Hibah P2M/III/2010Penelitian Nomor: 257/SP2H/PP/D, 1 Maret 2010

Rusdiyantoro, (2011), Product Green Design Development to Support Green Lifecycle Engineering Manufactured in Adibuana Metalworks, Prosiding International Conference on Creative Industry (ICCI), ISBN 978-979-781-8

Rusdiyantoro, (2013), Pengembangan Model Pendidikan Metode Just In Time (JIT), Penelitian Hibah Adi Buana2013

Setyo Purwoto, Yunia Dwie N, (2012), Portable Compact Reactors Water Treatment Berbasis Zeolit Dan Ion Exchange Terpadukan Dengan Reverse Osmosis (RO) Guna Mengatasi Kesulitan Air Layak Minum Masyarakat Pesisir, Laporan Penelitian Strategis Nasional 2012

Yunia Dwie N, (2008), Perancangan Produk Modular Untuk mendukung Green Lifecycle Engineering dengan Algoritme Genetik, Thesis 2008

Yunia Dwie N, (2011), Rancang Bangun Prototype Untuk Mempercepat Leadtime Pengembangan Produk Modular Serta Mendukung Green Lifecycle Engineering, Hibah Adi Buana DIPA 2011

Yunia Dwie N, Moses L Singgih, (2009), Quality function deployment implementation based on Fuzzy Kano model An Application on Product Green Life Cycle Engineering, International Journal of Design Taiwan, ISSN: 1991-3761 Eissn: 1994-036X

Yunia Dwie N, Prihono,(2011), Pengembangan Model Fuzzy Kano QFD Untuk Peningkatan Pelayanan Bis Kota berbasis Gender, Seminar Nasional Teknik Industri dan Kongres BKSTI VI Medan, Sumatra Utara, Prosiding ISBN 978-602-99977-0-5

Yunia Dwie N, Rusdiyantoro , (2010) , Perancangan Green Product di Lab Sistem Manufaktur Teknik Industri, Laporan IBIKK 2010

Yunia Dwie N, Rusdiyantoro, (2011), Pemetaan dan analisis sisi permintaan dalam dimensi kualitas, kuantitas, lokasi dan waktu di wilayah Surabaya, Sektor Perdagangan dan Jasa, dengan metode Fullfillment Index, Laporan Penelitian Penyelarasan Pendidikan dan Dunia Kerja 
Yunia Dwie N, Rusdiyantoro,(2012), Pemetaan dan analisis sisi pasokan dalam dimensi kualitas, kuantitas, lokasi dan waktu di wilayah Makasar dengan metode allignment index, Laporan Penelitian Penyelarasan dan Dunia Kerja

Yunia Dwie N, Setyo Purwoto, (2011), External Water Treatment for Feedwater Boiler, Prosiding International Conference on Creative Industry, ISBN : 978-979-8897-81-8, ITS Surabaya 